\title{
Hubungan Self Disclosure Dengan Kepercayaan Diri Siswa Dalam Mengemukakan Pendapat Di Depan Kelas X SMK Negri 9 Padang
}

\author{
Ade Nofembri ${ }^{1}$, Linda Fitria ${ }^{2}$, Popi Radyuli ${ }^{3}$ \\ ${ }_{1,2,3}$ Universitas Putra Indonesia YPTK Padang \\ Email : adenofembri03@gmail.com
}

\begin{abstract}
Abstrak
Penelitian ini dilatarbelakangi oleh karena masih rendahnya kepercayaan diri siswa dalam mengemukakan pendapat di depan kelas. Salah satu penyebabnya adalah rendahnya self disclosure siswa. Penelitian ini bertujuan untuk melihat gambaran kepercayaan diri, self disclosure, dan menguji hubungan self disclosure siswa dengan kepercayaan diri dalam menggungkapkan pendapat di depan kelas. Metode penelitian yang digunakan dengan pendekatan deskriptif dan korelasional. Populasi penelitian adalah siswa kelas sepuluh yang berjumlah 455 orang . Dengan sampel penelitian berjumlah 204 orang, yang dipilih dengan teknik purposive sample. Data dianalisis dengan teknik presentase dan untuk melihat hubungan kedua variabel menggunakan Pearson Correlation Product Moment. Hasil penelitian ditemukan (1) secara umum kepercayaan diri siswa berada pada kategori sedang, (2) secara umum self disclosure siswa berada pada kategori sedang, dan (3) terdapat hubungan yang signifikan antara self disclousure dengan kepercayaan diri siswa dengan $\quad$ rxy $=0,415$ dan taraf signifikansi 0,000. Berdasarkan temuan penelitian ini dapat menjadi acuan bagi siswa, tentang pentingnya meningkatkan self disclosure agar kepercayaan diri siswa dalam mengemukakan pendapat di depan kelas semakin meningkat. Selain itu guru BK dapat memberikan pelayanan konseling berdasarkan temuan penelitian ini.
\end{abstract}

Kata Kunci : Self Disclosure, Kepercayaan diri, Siswa.

\begin{abstract}
This research is motivated by the low self-confidence of students in expressing opinions in front of the class. One of the reasons is the low self-disclosure of students. This study aims to see a picture of self-confidence, self-disclosure, and to examine the relationship between students' self-disclosure and self-confidence in expressing opinions in front of the class. The research method used is descriptive and correlational approaches. The study population was the tenth grade students, amounting to 455 people. With a sample of 204 people, who were selected by purposive sample technique. Data were analyzed using percentage techniques and to see the relationship between the two variables using Pearson Correlation Product Moment. The results of the study were found (1) in general students 'self-confidence was in the medium category, (2) in general students' selfdisclosure was in the medium category, and (3) there was a significant relationship between self-disclosure and student self-confidence with rxy $=0.415$ and level significance of 0.000 . Based on the findings of this study, it can be a reference for students about the importance of increasing self-disclosure so that students' confidence in expressing opinions in front of the class increases. In addition, guidance and counseling teachers can provide counseling services based on the findings of this study.
\end{abstract}

Keyword : Self Disclosure, Confidence, Students.

\section{PENDAHULUAN}

Pendidikan merupakan suatu hal yang penting dan tidak dapat di pisahkan dari kehidupan seseorang. Baik dalam keluarga, masyarakat dan bangsa. Kemajuan suatu bangsa ditentukan oleh tingkat keberhasilan pendidikan. Indonesia sebagai negara berkembang dalam pembangunan membutuhkan 
sumber daya manusia yang dapat di andalkan. Tujuan pendidikan nasional adalah mengembangkan potensi siswa agar menjadi manusia yang beriman dan bertakwa kepada Tuhan Yang Maha Esa, berakhlak mulia, sehat, berilmu, cakap, kreatif, mandiri, dan menjadi warga negara yang demokratis serta bertanggung jawab (UU Sisdiknas tahun 2003). Dengan adanya pandemi covid 19, untuk mencapai tujuan pendidikan agaknya terjadi kendala, sehingga terjadi perubahan pada sistem pendidikan, khususnnya di Indonesia. Pandemi Covid 19 yang melanda dunia dapat melumpuhkan beberapa sektor dan melemahkan dalam berbagai aspek, terutamanya di bidang pendidikan seperti yang di sampaikan Rahmawati (2020) menjelaskan bahwa masyarakat dihadapkan perubahan dalam segala sisi dan membuat banyak orang shock dan kaget baik dari sektor ekonomi, sosial dan tidak menutup kemungkinan bahwa dampak lainnya dari Covid-19 lainnya adalah perubahan perilakunya itu sendiri. Pemerintah juga mengimbau untuk melakukan aktivitas dilakukan di rumah saja seperti work from home bagi pekerja di berbagai bidang, pemberhentian aktivitas sekolah - sekolah dan perguruan tinggi dan pemberlakuannya pembatasan sosial berskala besar (PSBB) dimana para pengendara diwajibkan mengikuti beberapa peraturan tertentu apabila ingin berpergian.

Metode belajar di sekolah pun berubah secara signifikan akibat adanya pandemi covid 19. Siswa sebagai individu yang menjadi sasaran tujuan pendidikan sangat merasakan dampak yang ditimbulkan oleh pandemi covid 19. Proses belajar mengajar antara pendidik dan siswa tidak lagi seperti biasanya. Tidak ada siswa yang datang ke sekolah untuk menjalani proses belajar mengajar. Mereka belajar dari rumah dengan menggunakan sistem online sejak bulan maret tahun 2020 sampai desember 2020. Pembelajaran tatap muka baru dimulai bulan januari 2021, itupun belum sepenuhnya tatap muka. Proses belajar mengajar dilakukan dengan sistem kombinasi antara daring dan tatap muka. Siswa yang sudah lama tidak belajar tatap muka di sekolah merasa canggung dan tidak terbiasa lagi bercerita maupun mengemukakan pendapat di kelas. Kondisi ini merupakan salah satu indikator rendahnya kepercayaan diri siswa, terutama saat proses belajar mengajar di kelas. Berbeda dengan siswa yang memiliki kemampuan keterbukaan diri/ self disclosure, individu yang self disclosure nya tinggi cenderung memiliki kepercayaan diri yang tinggi.

Ada beberapa faktor yang mempengaruhi kepercayaan diri yaitu harga diri, konsep diri, keterbuaan diri/ self disclosure, dan pendidikan (Ashali et al., 2015). Individu yang kompeten lebih banyak melakukan pengungkapan diri (self-disclosure) akan meningkatkan rasa percaya diri. Dasar teori ini memunculkan asumsi bahwa semakin orang percaya diri, semakin mudah mengungkapkan keadaan dirinya kepada orang lain. Pengungkapan diri mengindikasikan seorang siswa melakukan interaksi dengan orang lain, yang berarti bahwa rasa percaya diri itu terkandung di dalam proses ketika keorang siswa berusaha mengungkapakan keadaan dan perasaannya kepada siswa lain.

Self disclosure adalah ungkapan reaksi atau tanggapan individu terhadap situasi yang sedang dihadapi serta memberikan informasi tentang masa lalu yang relevan atau yang berguna untuk memahami tanggapan kita dimasa kini sehingga memunculkan keberanian berpendapat dengan pengalaman yang telah dilewati di masa lalu untuk menanggapi apa yang terjadi di masa sekarang (Kumalasari \& Desiningrum, 2016). Sikap self disclosure membuka diri ini dapat bersifat deskriptif atau evaluatif. Deskriptif artinya individu melukiskan berbagai fakta mengenai diri sendiri yang mungkin belum diketahui oleh pendengar seperti, jenis pekerjaan, alamat dan usia, sedangkan evaluatif artinya individu mengemukakan pendapat atau perasaan pribadinya seperti tipe orang yang disukai (Gainau, 2012). Self disclosure ini dapat berupa berbagai topik seperti informasi, perilaku, perasaan, keinginan, motivasi dan ide yang sesuai dan terdapat di dalam diri yang bersangkutan. Kedalaman dari pengungkapan diri seseorang tergantung pada situasi dan orang yang diajak berinteraksi.

Banyak sekali anak yang ditemui dalam lingkungan mengalami masalah karena dia tidak mau menceritakan, masalahnya kepada orang yang lebih dewasa darinya, ataupun kepada teman sebayanya dan orang-orang disekitarnya karena tidak percaya diri. Kepercayaan diri menjadi bagian penting dalam perkembangan kepribadian seseorang sebagai penentu bagaimana bersikap bertingkah laku dan mengungkapkan pendapat serta menanggapi pendapat (Hakim, 2002 ). Rasa percaya diri seseorang adalah salah satu kekuatan jiwa yang sangat menentukan berhasil tidaknya orang tersebut dalam mencapai berbagai tujuan hidupnya. Percaya diri itu tumbuh dari dalam hati seseorang, 
menyatu dengan jiwanya di aplikasikan dengan sikapnya. Kepercayaan diri menuntun individu menuju ke arah keberhasilan.

Berdasarkan observasi awal yang dilakukan peneliti pada tanggal 23 November 2020, dan didukung dengan wawancara kepada siswa pada saat sedang melakukan magang di SMKN 9 Padang, setelah dilakukan observasi, wawancara dan konseling individual pada siswa banyak ditemukan siswa tidak mau terbuka dengan permasalahan yang sedang dihadapinya dan cenderung tidak percaya diri dalam belajar maupun dalam menentukan teman serta kurang aktif dalam belajar dan rendahnya kreativitas dalam dalam belajar dan menanggapi apa yang disampaikan guru saat proses dalam belajar. Hal ini dilihat ketika saat proses belajar, hal ini juga terungkap setelah dilakukanya konseling individual terhadap siswa tersebut juga menemukan rendahnya rasa percaya diri untuk menyampaikan pendapatnya karena malu katanya kepada konselor, siswa ini dapat terlihat ketika dia belajar dan keaktifan dalam belajar di kelas siswa akan merasa malu untuk menanyakan pelajaran yang ia tidak mengerti, siswa lebih memilih diam dari pada bertanya karena merasa tidak percaya diri atau malu karena nantinya di anggap bodoh oleh teman - temanya. Dengan kurangnya kepercayaan diri siswa tidak hanya akan menimbulkan hasil belajarnya yang tidak sesuai yang di inginkan, namun juga akan mengganggu hubungan sosialnya dalam lingkungan bermasyarakat dan susah baginya untuk beradaptasi dengan lingkungan baru, dia hanya bergaul dengan lingkungan yang dominan keluarganya sendiri dan cenderung tidak ingin bergaul dengan orang-orang baru terutama di lingkungan sekolah.

Jika hal ini dibiarkan akan berdampak pada perkembangan pribadinya serta kepercayaan dirinya dalam mengambil keputusan tentang masalah yang menimpanya, jika hal berlanjut ke fase-fase berikutnya dan akan menimbulkan masalah yang akan membuatnya tertekan karena tidak mau menceritakan masalahnya serta akan membuat dia tidak mencapai kepribadian yang sehat dan membuat siswa menjadi tidak terampil dimasa yang akan datang, sehingga membuat hal yang ingin dia capai akan sulit tercapai dan mudah untuk putus asa tentang apa yang dia inginkan serta apa yang akan dia lakukan.

\section{METODOLOGI}

Penelitian ini menggunakan pendekatan kuantitatif yang berbentuk deskriptif korelasional. Sampel penelitian ini adalah siswa kelas $\mathrm{X}$ di SMKN 9 Padang. Teknik pengumpulan data menggunakan kuisioner. Data dianalisis dengan teknik analisis deskriptif dan analisis korelasional. Pengujian hipotesis penelitian menggunakan rumus korelasi Pearson Product Moment. Uji korelasional dilakukan dengan memanfaatkan program Statistical Product and Service Solution (SPSS) Versi 20.0. dan Microsoft Excell 2007.

Bagan kerangka konseptual dalam penelitian dapat digambarkan secara praktis seperti gambar dibawah ini:

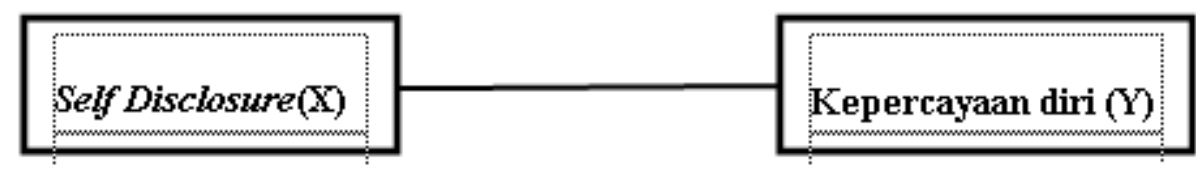

Gambar 1: Kerangka Kerangka Konseptual Hubungan antara Pengungkapan Diri (Self-Disclosure) dengan Kepercayaan Diri

Kerangka konseptual bertujuan untuk menggambarkan penelitian secara garis besar. Dimana yang menjadi variabel bebas pada penelitian ini adalah self disclosure (keterbukaan diri ) dan variabel terikat adalah kepercayaan diri. Seorang siswa yang memiliki tingkat kepercayaan dirinya tinggi cenderung memiliki kepercayaan diri dalam hal mengemukakakn pendapat di depan kelas. 


\section{HASIL DAN PEMBAHASAN}

Berdasarkan hasil pengolahan data sebelumnya maka dapat dijabarkan hasil penelitian sebagai berikut: (1) untuk mendeskripsikan tingkat pengungkapan diri (self-disclosure) siswa, (2) untuk mendeskripsikan tingkat kepercayaan diri siswa dan (3) untuk menguji apakah terdapat hubungan yang signifikan antara pengungkapan diri (self-disclosure) dengan kepercayaan diri siswa kelas $\mathrm{X}$ dalam mengemukakan pendapat. Gambaran pengungkapan diri (self-disclosure) remaja dapat dilihat pada Tabel 1.

Tabel 1: Distribusi Frekuensi dan Persentase Pengungkapan Diri (Self-Disclosure)(N=204)

\begin{tabular}{lccc}
\hline \multicolumn{1}{c}{ Kategori } & Rentang skor & Responden & Persentase \\
\hline Rendah & $<84$ & - & $0 \%$ \\
Sedang & $84-126$ & 129 & $63,2 \%$ \\
Tinggi & $>126$ & 75 & $36,8 \%$ \\
Jumlah & & 204 & $100 \%$
\end{tabular}

Data pada Tabel 1 dapat diketahui bahwa responden yang memiliki tingkat self disclosure sedang sebesar 63,2\% dan sisanya 36,8\% memiliki tingkat self disclosure tinggi. Self disclosure merupakan tindakan untuk mengungkapkan tentang bagaimana kita berinteraksi dengan orang terhadap situasi yang terjadi saat ini, dan memberikan informasi tentang masa lalu yang relevan, yang dapat menjelaskan reaksi yang kita perbuat saat ini. Setiawati (2012) mengemukakan bahwa pengungkapan diri (self disclosure) adalah proses menghadirkan diri dalam kegiatan berupa berbagai topik seperti informasi yang akrab, informasi perilaku, sikap, membagi perasaan, keinginan, motivasi, dan ide. Keterbukaan diri adalah jenis komunikasi dimana individu mengungkapkan informasi tentang dirinya yang biasanya disembunyikan atau tidak diceritakan kepada orang lain. Istilah keterbukaan diri mengacu pada pengungkapan informasi secara sadar (Devito, 2011: 64). Pengungkapan diri atau self disclosure dapat diartikan sebagai pemberian informasi tentang diri sendiri kepada orang lain. Informasi yang diberikan tersebut dapat mencakup berbagai hal seperti pengalaman hidup, perasaan, emosi, pendapat, cita-cita, dan lain sebagainya. Pengungkapan diri haruslah dilandasi dengan kejujuran dan keterbukaan dalam memberikan informasi, atau dengan kata lain apa yang disampaikan kepada orang lain hendaklah bukan merupakan suatu topeng pribadi atau kebohongan belaka sehingga hanya menampilkan sisi yang baik saja. Gambaran penyesuaian diri remaja dapat dilihat pada Tabel 2.

Tabel 2: Distribusi Frekuensi dan Persentase Kepercayaan Diri Siswa Berpedapat di Depan Kelas $(\mathrm{N}=204)$

\begin{tabular}{lccc}
\hline Kategori & Rentang skor & Responden & Persentase \\
\hline Rendah & $<72$ & - & $0 \%$ \\
Sedang & $72-108$ & 143 & $70,1 \%$ \\
Tinggi & $>108$ & 61 & $29,9 \%$ \\
Jumlah & & 204 & $100 \%$ \\
\hline
\end{tabular}

Berdasarkan hasil pengolahan data yang diperoleh dari responden dapat diketahui bahwa 143 responden memiliki tingkat kepercayaan diri sedang atau sebesar $70,1 \%$, dan sisanya 61 orang 
memiliki tingkat kepercayaan diri tinggi atau sebesar 29,9\%. Percaya Diri adalah meyakinkan pada kemampuan dan penilaian (judgement) diri sendiri dalam melakukan tugas dan memilih pendekatan yang efektif. Hal ini termasuk kepercayaan atas kemampuannya menghadapi lingkungan yang semakin menantang dan kepercayaan atas keputusan atau pendapatnya. Sedangkan kepercayaan diri adalah sikap positif seorang individu yang memampukan dirinya untuk mengembangkan penilaian positif baik terhadap diri sendiri maupun terhadap lingkungan atau situasi yang dihadapinya. Setianingsih (2015) mendefinisikan kepercayaan diri merupakan modal dasar keberhasilan di segala bidang. Pendapat tersebut dapat diartikan bahwa kepercayaan diri merupakan titik awal yang dapat menentukan pencapaian cita-cita atau impian yang ada di dalam diri individu. Dengan kata lain, awal tercapainya cita-cita seseorang ditentukan oleh keyakinan kuat dalam diri untuk meraih cita-cita yang didambakan. Pendidikan di sekolah juga merupakan lingkungan yang sangat berperan penting dalam menumbuhkembangkan kepercayaan diri anak. Individu yang mempunyai kepercayaan diri yang tinggi akan terlihat lebih tenang, tidak memiliki rasa takut, dan mampu memperlihat kan kepercayaan dirinya setiap saat. Sedangkan bagi mereka yang tidak percaya diri, setiap kegagalan mempertegas rasa tidak mampu mereka. Tidak adanya percaya diri dapat mewujud dalam bentuk rasa putus asa, rasa tidak berdaya, dan meningkatnya keraguan kepada diri sendiri. Selain itu, percaya diri yang berlebihan dapat membuat orang tampak sombong, terutama bila ia tidak mempunyai keterampilan sosial. Kepercayaan diri juga sangat penting bagi seseorang untuk dapat mengembangkan potensinya. Jika seseorang memiliki bekal kepercayaan diri yang baik, maka individu tersebut akan dapat mengembangkan potensinya dengan mantap (Fahmi \& Slamet, 2017). Kepercayaan diri membuat siswa berani mengemukakan pendapat ketika diperintahkan guru maupun secara sukarela. Kepercayaan diri membantu siswa mencapai prestasi dan hasil belajar yang lebih baik lagi. Hasil analisis korelasi antara pengungkapan diri (self-disclosure) dengan kepercayaan diri siswa dalam berpendapat di depan kelas dipaparkan pada Tabel 3.

Tabel 3: Pengungkapan Diri (Self Disclosure) dan Kaitanya dengan Kepercayaan Diri Siswa

\begin{tabular}{|c|c|c|c|}
\hline Variabel & $\mathrm{N}$ & r-hitung & Sign \\
\hline Pengungkapan & \multirow{3}{*}{143} & \multirow{3}{*}{0,415} & \multirow{3}{*}{0.000} \\
\hline Diri $\quad$ (Self- & & & \\
\hline Kepercayaan Diri & & & \\
\hline
\end{tabular}

Data pada Tabel 3 memperlihatkan besarnya nilai koefisien korelasi antara variabel pengungkapan diri (self-disclosure) (X) dengan kepercayaan diri (Y), yaitu 0,415 dengan signifikansi 0,000 yang lebih kecil dari 0,05 . Hal tersebut menunjukkan bahwa adanya hubungan yang signifikan antara pengungkapan diri (self-disclosure) dengan kepercayaan diri siswa dalam hal berpendapat di depan kelas. Artinya, jika semakin tinggi pengungkapan diri (self-disclosure) maka kepercayaan dirinya akan semakin baik.

Penelitian ini sejalan dengan penelitian yang dilakukan oleh Rahmawati (2014) hubungan antara kepercayaan diri dengan pengungkapan diri (self disclosure). Dari hasil penelitian menunjukkan bahwa ada hubungan positif dan sangat signifikan antara kepercayaan diri dengan pengungkapan diri dengan nilai koefisien korelasi $(r)=0.551$ dan probabilitas kesalahan $(\mathrm{p})<0.01$. Hal ini berarti semakin tinggi tingkat kepercayaan diri maka semakin tinggi pula pengungkapan yang dilakukan. 
Sebaliknya semakin rendah kepercayaan diri maka semakin rendah pula pengungkapan yang dilakukan. Selanjutnya, Rahmadhaningrum (2013) menguji hubungan kepercayaan diri dan pengungkapan diri siswa SMA terbuka Kepanjen. Hasil penelitian menunjukkan kepercayaan diri siswa SMA Terbuka sebagian besar berada dalam kategori sedang sebanyak.pengungkapan diri siswa SMA Terbuka sebagian besar berada dalam kategori sedang. Ada hubungan antara kepercayaan diri terhadap pengungkapan diri remaja dengan nilai $r=0,463$, nilai $p=0,001<0,05$, menunjukkan bahwa semakin keterbukaan diri kepercayaan diri maka semakin tinggi pengungkapan diri.

\section{KESIMPULAN}

Berdasarkan penelitian dan pembahasannya, dapat ditarik kesimpulan sebagai berikut: (a) pengungkapan diri (self-disclosure) siswa secara umum berada pada kategori sedang, (b) kepercayaan diri siswa dalam hal mengemukakakn pendapat di depan kelas secara umum berada pada kategori sedang, (c) terdapat hubungan yang positif dan signifikan antara pengungkapan diri (self-disclosure) dengan kepercayaan diri siswa dalam hal mengemukakan pendapat di depan kelas.

Berdasarkan hasil penelitian maka peneliti mengemukakan beberapa saran, sebagai berikut: (a) perlu adanya tindak lanjut untuk meningkatkan self disclosure siswa, terlebih jika memang ada permasalahan yang membutuhkan keterbukaan diri siswa yang bersangkutan. Dalam hal ini orang tua juga dapat membantu karena berdasarkan hasil penelitian terdapat pengaruh lingkungan yang dalam hal ini termasuk orang tua, (b) bagi siswa diharapkan agar memiliki kesadaran untuk lebih meningkatkan self disclosure mereka khususnya jika informasi tersebut memang penting dan justru mampu membantu permasalahan serta perkembangan diri mereka, (c) peneliti selanjutnya dapat menjadikan hasil penelitian ini sebagai bahan rujukan untuk meneliti permasalahan tentang pengungkapan diri (self-disclosure) dan kepercayaan diri secara lebih luas berkaitan dengan faktor internal dan eksternal lainnya.

\section{DAFTAR PUSTAKA}

${ }^{[1]}$ Ashali, H. L., Wagimin, \& Hidayat, R. R. (2015). Kepercayaan Diri Ditinjau Dari Self-Disclosure dan Tingkat Ekonomi Orangtua pada Siswa SMP di Sukoharjo. CONSILIUM : Jurnal Program Studi Bimbingan Dan Konseling, 3(June).

${ }^{[2]}$ DeVito, J. A. (2011). Komunikasi antar manusia. Jakarta: Professional Books.

${ }^{[3]}$ Fahmi, N. N., \& Slamet, S. (2017). Layanan Konseling Kelompok Dalam Meningkatkan Rasa Percaya Diri Siswa Smk Negeri 1 Depok Sleman. Hisbah: Jurnal Bimbingan Konseling Dan Dakwah Islam, 13(2), 69-84. https://doi.org/10.14421/hisbah.2016.132-05

${ }^{[4]}$ Fatchurahman, M., \& Pratiko, H. (2012). Kepercayaan Diri, Kematangan Emosi, Pola Asuh Orang Tua Demokratis dan Kenakalan Remaja. Persona:Jurnal Psikologi Indonesia, 1(2). https://doi.org/10.30996/persona.v1i2.27

${ }^{[5]}$ Gainau, M. B. (2012). Keterbukaan Diri. Sekolah Tinggi Agama Kristen Protestan Negeri (STAKPN) Papua, 12-36.

${ }^{[6]}$ Ghufron, M. N., \& Risnawita, R. S. (2010). Teori-Teori Psikologi. Jogjakarta: Ar-Ruzz Media. 
${ }^{[7]}$ Hakim, T. 2005. Mengatasi Rasa Tidak Percaya Diri. Jakarta: Purwa Suara.

${ }^{[8]}$ Kumalasari, A. G., \& Desiningrum, D. R. (2016). Hubungan Antara Dukungan Sosial Guru Dengan Pengungkapan Diri (Self Disclosure) Pada Remaja. Empati, 5(4), 640-644.

${ }^{[9]}$ Lauster, P. (2010). Tes Kepribadian.Jakarta : Gaya Media Pratama.

${ }^{[10]}$ Racmat, J. (2000). Psikolgi Komunikasi. Bandung: PT. Remaja Rosdakarya.

${ }^{[11]}$ Rahmadhaningrum, A. (2013). Hubungan keterbukaan diri (self-disclosure) dengan interaksi sosial remaja di SMA Negri 3 Bantul Yogyakarta. 2.

${ }^{[12]}$ Rahmamawati (2014). Skripsi Hubungan keterbukaan Diri dengan kepercayaan diri interpesona pada siswa VIII SMP N 1 Melati Slema. Yokyakarta.

${ }^{[13]}$ Retno Puspito Sari, Tri Rejeki A. \& Achmad M.M. (2006). Pengungkapan Diri Mahasiswa Tahun Pertama Universitas Diponegoro Ditinjau dari Jenis Kelamin dan Harga Diri. Jurnal Psikologi Universitas Diponegoro, 3(2): 11-25.

${ }^{[14]}$ Riduwan. (2010). Belajar Mudah Penelitian Untuk Guru-Karyawan dan Peneliti Pemula. Bandung: Alfabeta.

${ }^{[15]}$ Setianingsih, E. S. (2015). KETERBUKAAN DIRI SISWA (Self Disclosure). Journal of Chemical Information and Modeling, 2(2), 1689-1699.

${ }^{[16]}$ Setiawati, D. (2012). Efektivitas model knap untuk meningkatkan keterbukaan diri siswa SMA. Jurnal Psikologi Pendidikan Dan Bimbingan, 13(1), 17-26. http://ejournal.unesa.ac.id/article/8301/75/article.pdf

${ }^{[17]}$ Undang-undang No.20 Tahun 2003 tentang Sistem Pendidikan Nasional. Jakarta: Depdiknas. 